\title{
Leuchttürme und Durchlauferhitzer
}

\author{
Joachim Hertzberg
}

Online publiziert: 18. Juni 2013

(C) Springer-Verlag Berlin Heidelberg 2013

\section{Liebe Leserin, lieber Leser!}

Ganz früher baute man Leuchttürme ja aus Steinen. So ein Leuchtturm stand sichtbar in Sturm und Gischt, und gelegentlich wurde er renoviert oder bekam eine bessere Lampe. Irgendwann geschah es, dass die Zeit über ihn hinwegging und er nicht mehr als Leuchtturm gebraucht wurde; dann steht er aber meist dennoch bis heute mit all seinen Dauersteinen da und dient als Aussichtsplattform oder als Location in der Bierreklame.

Wenn Politiker oder Journalistinnen von Leuchttürmen in der Wissenschaft schreiben, dann meinen sie mit der Metapher natürlich immer nur einen Aspekt der echten Leuchttürme: Sichtbar zu stehen in Sturm und Gischt. Schon das Renovieren öffentlicher Gebäude ist bekanntlich ein schwieriges Thema, wie unsere Schul- und Hochschulgebäude überreich belegen. Massenhaft Dauersteine, nein, Dauerstellen in solchen metaphorischen Leuchttürmen einzubauen, auf dass sie dauerhaft stehen - das geht heute natürlich gar nicht! Und das führt uns zum Durchlauferhitzer.

Der damalige Bundesforschungsminister Dr. Heinz Riesenhuber fand den Mitte der 1980er Jahre als die dezent menschenverachtende Metapher für Forschungsinstitute, in die junge Nachwuchsleute zum Promovieren oder als Postdocs auf Zeit hineingehen, forschen und nach einigen Jahren das Institut auf verbesserte Qualifikation ,erhitzt“ Richtung Wissenschaft oder Wirtschaft verlassen. Das klingt heute normal; damals war es das zumindest für die außeruniversitären Institute überhaupt nicht. Im Gegenteil erinnere ich mich an den Kulturschock, den diese Metapher in dem Institut auslöste, in dem ich damals arbeitete (in der GMD, damals ein Institut der Helmholtz-Gemeinschaft), und ich sel-

J. Hertzberg ( $\varangle)$

Universität Osnabrück, Osnabrück, Deutschland

e-mail: Joachim.hertzberg@uos.de ber fand sie auch unplausibel. Das DFKI, auf dessen 25-ten Geburtstag das kommende Heft eingehen wird, verkörperte diese Durchlauferhitzer-Metapher ab seiner Gründung, die genau in diese Zeit fiel.

Heute gestehe ich, meiner damaligen Skepsis zum Trotz, dass Minister Riesenuber zumindest für die Informatik/ Informationstechnik mit seiner Idee Recht hatte - auch wenn mir die Metapher nach wie vor missfällt. Gerade in der KI sind in den letzten drei Jahrzehnten unter diesem Modell eine beeindruckende Zahl von Nachwuchswissenschaftler/innen auf höchstes Niveau gebildet und ausgebildet worden, und zwar nicht allein von den Universitäten, sondern gerade auch von Forschungsprogrammen, Instituten und Verbünden, die im Konzert mit Hochschulen oder in ihnen erfolgreich eine Durchlauferhitzer-Rolle gespielt haben. Das DFKI selbst ist hier prominent zu nennen; doch auch andere außeruniversitäre Institute, SFBs, Graduiertenschulen und dergleichen haben zu dem Erfolg beigetragen.

Das Durchlauferhitzen macht aber natürlich nur dann Sinn, wenn der Hochqualifizierung von Nachwuchsleuten ein Angebot entsprechender Stellen für die Zeit danach gegenübersteht. Das scheint in der Vergangenheit im Großen und Ganzen funktioniert zu haben, wenn man die eine oder andere Karriere einrechnet, die ursprünglich vielleicht planwidrig, letztendlich aber erfolgreich verlaufen ist, zum Beispiel über eine Professur im Ausland oder eine interessante Stelle in der Wirtschaft.

Dass das so positiv bleibt, scheint mir aber derzeit nicht ausgemacht zu sein.

Das Gleichgewicht des Betriebs von Leuchttürmen und Durchlauferhitzern in der deutschen KI der letzten Jahre scheint gefährdet. Ausweislich Kollegengesprächen am Rand von Fachtagungen gibt es einerseits europaweit derzeit ein Überangebot von Durchlauferhitzern, was mit einem Unterangebot von mindestens sehr guten Graduierten und 
Postdocs korrespondiert. Andererseits scheint die Diskussion in der Politik über eine stärkere Differenzierung zwischen explizit geförderten Leuchttürmen der Wissenschaft und einem in der breiten Basis eher niveaugedeckelten Rest nicht abzureißen; jüngstes Beispiel ist der vorab bekannt gewordene Entwurf des Wissenschaftsrats zum „Zukunftspakt 2022“. Eine Reduktion des Qualitätsanspruchs in der Fläche in der hochschulischen und außerhochschulischen KI-Forschung und Bildung nimmt aber dem gerade frisch durchlauferhitzten wissenschaftlichen Nachwuchs die Perspektive auf eigene Forschung, die ihrer mit Aufwand auf allen Seiten erzielten hohen wissenschaftlichen Qualifikation entspricht. Den Leuchttürmen entzieht sie gleichzeitig die notwendige Basis. Anders als steinerne Leuchttürme in Sturm und Gischt sind die der Wissenschaft auf den ständigen Durchlauf von Menschen mit exzellenten Ideen angewiesen. Reduktion des wissenschaftlichen Qualitätsanspruchs in der Fläche schafft kurzfristig vielleicht freies Geld für die Leuchttürme; langfristig führt es dazu, dass die Hochschulen und Institute im Hinterland weniger sehr gut gebildete Nachwuchsleute schaffen, die Talent und Fähigkeiten haben, sich im Leuchtturm durchlauferhitzen zu lassen und ihn damit zum Leuchten zu bringen.

Bei Minister Riesenhubers Durchlauferhitzergedanken in den 1980ern habe ich mit meiner skeptischen Einschätzung daneben gelegen. Ich hoffe, dass das jetzt wieder so ist.

Freundliche Grüße, Joachim Hertzberg

\section{Forthcoming Special Topics}

\section{Artificial Intelligence in Agriculture}

Besides the three classical production factors land, labor and capital, the factor "information and knowledge" becomes more and more important. This specifically holds for the agricultural domain because we are faced to the challenge that we have to double the crop yields until 2050 to feed the expended 9 Billion of people worldwide. Since the amount of arable land in developed countries is shrinking we have to concentrate on the better employment of knowledge and technology. This way, GPS with its area-wide spatial reference service already enabled a new dimension to the optimization of production processes in crop farming. In addition, first approaches of a standardized IT-infrastructure realize a promising basis to exploit the growing availability of geospatial information, reliable weather forecasts, soil quality records, status reports about plants, tips for yield optimization and environmental protection towards a better economizing. The Web of Services in combination with mobile networks allows that a future GPS- and sensor-based tractor connects to the wireless sensor network of the present cropland in order to query the current soil moisture and other parameters to optimize upcoming tasks and workflows.

Especially for the Artificial Intelligence, this context reveals a variety of high-potential technologies to be applied, as the agricultural and environmental domains provide a steadily growing pool of publicly accessible knowledge, which is financed and maintained from governmental organizations. Innovative AI technologies can significantly contribute to organize, connect, and further develop this knowledge in order to better supply the collective demand for food.

Topics for the call-for-papers (not limited to) are:

- Instrumentation and Sensor Technology

- Information Management

- Ergonomics in Agriculture and Food Processing

- Environment Control

- Data Mining

- Location-based Services

- Forecasting Systems

- Robotics and Mechatronics

- Resource Planning

- Mobile, Collaborative Agents

- Innovative Interaction/Operating Concepts/Paradigms

- Optimization of Value Chains

- Intelligent Soil Management (Cultivation of Land)

- AI-based Evaluation and Decision Making

- Precision Agriculture

- Simulation

In addition to technical research papers, this special issue will accept reports from project and dissertations as well as discussion and market reports. This should provide a comprehensive overview of current activities in this area. Interested authors are asked to contact the guest editor of this issue a soon as possible:

Interested authors are asked to contact the guest editor as soon as possible:

\section{Prof. Dr. Prof. h.c. Andreas Dengel}

German Research Center for Artificial Intelligence (DFKI)

Trippstadter Str. 122, D-67663 Kaiserslautern

Phone +49-631-20575-1000

Fax +49-631-20575-1020

E-Mail: andreas.dengel@dfki.de

\section{Transfer Learning}

Machine learning research for a long time has focused on tabula rasa approaches, i.e. learning techniques that start from scratch without exploiting the potential of prior experience gained on other tasks. Transfer learning attempts to tap 
into this potential, viewing learning as a life-long process where everything learned can be used to speed up and improve future learning performance. In this context, past experience can be in terms of the knowledge and skills gained through learning, as well as the learning process itself.

This special issue will cover all aspects of transfer learning, including but not limited to:

- Knowledge, task, and state-space representation

- Inter-task mappings of states and actions

- Source task selection

- Evaluation methods

- Reward shaping

- Meta learning

- Life-long learning

- Applications, e.g. robotics.

We are seeking a wide range of contribution formats for the special issue, e.g. technical articles, surveys, interviews, project descriptions, and lab portraits.

Interested authors are asked to contact the guest editor as soon as possible:

\section{Dr. Daniel Kudenko}

Department of Computer Science

University of York

York, YO105GH

United Kingdom

E-Mail:kudenko@cs.york.ac.uk

\section{Space Robotics}

While Space Exploration may be considered anything but dull, it certainly is very dangerous. Expanding our knowledge on the solar system to look for clues to such fundamental questions as the origins of life, or a sustained human presence on anything other than earth may well be worth the risk. The involved costs for mitigating the risk of human space flight are prohibitive. Robotic missions, like the hugely successful Mars Exploration Rovers, have shown that Robotics as a sub-field of Artificial Intelligence can perform scientific exploration activities without human presence, and will play an even more prominent role in future mission scenarios. World wide technology research efforts are continuously expanded the capabilities of mobile robotic systems. This special issue on "Space Robotics" of the KI Journal seeks to present a collection of research efforts, industry activities and other insights into this hugely interesting and versatile field of AI.

The topics of interest include, but are not limited to:

- Exploration systems and technologies

- Orbital servicing

- Human mission support

- Operations support

- System design/architecture/behavior

The KI Journal, which is published and indexed by Springer, supports the following lists of formats: Technical contributions, research projects, discussions, dissertation abstracts, conference reports and book reviews.

Interested authors should contact the guest editor as soon as possible:

\section{Jakob Schwendner}

Robotics Innovation Center

Deutsches Forschungszentrum für Künstliche Intelligenz (DFKI)

28359 Bremen

E-Mail: jakob.schwendner@dfki.de

\section{Prof. Dr. Frank Kirchner}

Robotics Innovation Center

Deutsches Forschungszentrum für Künstliche Intelligenz (DFKI)

28359 Bremen

E-Mail: frank.kirchner@dfki.de

\section{Dr. Bernd Sommer}

Deutsches Zentrums für Luft- und Raumfahrt (DLR)

Königswinterer Straße 522-524

53227 Bonn

E-Mail: Bernd.Sommer@dlr.de 